\title{
Exploring potential locally available feedstuffs for diversifying pig's feeds in dry land area (Part 2: Stem and Leaves sources)
}

\begin{abstract}
The study aimed at observing potential locally available feedstuffs for pigs in Nusa Tenggara Timur (NTT) Province- one of the southeast Indonesia region of Indonesia- with highest pig population in Indonesia. There were 2 potential locally available feedstuffs from 2 sources of feedstuffs consisting of Putak (stems), and Moringa leaf (leaves) observed by using survey method. The survey was carried out in 13 of 22 districts of dry land area Nusa Tenggara Timur Province. Farmers, producer, collectors, traders, and agencies involved in planting, collecting, selling and trading feedstuffs were interviewed to collect primary data. Agricultural and Animal Departments and Statistics data were browsed to collect secondary data. Data of seasonal availability, price and nutritional content of each commodity were collected and descriptively analyzed. The results found were that the 2 feedstuffs explored are adaptable with dry land climate. Putak is generated commonly used in 5 districts, produced independently of season, it is feasible with enriching nutrient content and mixed with other feedstuffs. Moringa leaf is available in all districts, produced whole year with lower during the dry season. Moringa leaf is not recorded in all districts. Putak is fibrous with low protein content and need additional treatment to maximum utilized by pig; it can not be used as single feed for pig. Moringa leaf contains high protein and highest value for pig can be achieved by drying and milling, or soaking the fresh leaves into water, or pulping the fresh leaves before feeding. Moring leves meal can be used as a green supplement for pig.
\end{abstract}

Keywords: local feedstuff, stem, leaf, fibrous, green
Volume 4 Issue 5 - 2020

\author{
Johanis Ly,' Teddy Kristeddy² \\ 'Faculty of Animal Husbandry, Nusa Cendana University, \\ Indonesia \\ ${ }^{2}$ Applied Research and Innovation Systems in Agriculture \\ (ARISA)/Commonwealth Scientific and Industrial Research \\ Organisation (CSIRO), Indonesia
}

Correspondence: Johanis Ly, Faculty of Animal Husbandry, Nusa Cendana University, Indonesia, Tel 62-380-881580, Fax+62-380-881674, Email johansly@gmail.com

Received: August 10,2020 | Published: October 30, 2020

\section{Introduction}

Nusa Tenggara Timur (NTT) Province- one of the southeast Indonesia region of Indonesia-is not only wealthy in local available seeds and tubers but also plenty in stems and leaves sources for pigs. ${ }^{1}$ Indeed, there were various stem and leaves sources feeds available and have been traditionally generated used in this region, but unfortunately, farmers have low knowledge incomprehend feeds' seasonal availability, nutritional contents and skill in processing and composing locally available feedstuffs for pigs. ${ }^{2}$ These constraints have resulted in remain only one stem and one leaves source being used, although with poor performance results of the pig. ${ }^{3}$ This articleexplores the potency of the generated potential commonly pig's local stem and leaves sourcefeedstuffs, by mapping their seasonal availability, economic view and nutritional content of those feedstuffs in dryland of southeast Indonesia. This article is the second part of the previous article in fruits, seeds, and tubers that has been published in BIJ Volume 3 Issue 3 2019, May 2019. ${ }^{4}$ The article rolls out the potency, availability, marketing, ingredients and utilization of "Putak" as a stem feed source and Moringa leaf as a leaves feed sources.

The provided information could be an entrusted input for pig farmers in using Putak and Moringa leaves and for feed manufactures in utilizing these local feeds. Data provided in this article were as part of whole observed data of a study proposed to explorethe availability of the most common locally pig's feedstuffsby evaluating their potential production and those feed ingredients, and economic feasibility.

\section{Materials and methods}

There were 2 commonly used locally available pigs feedstuffs observed in the study: Corypha gebanga stalk (called putak simlar to sago) as a stem feed source, and moringa (leaves) represents leaves sources. The study was carried out by survey method in 13 of 22 districts, ${ }^{5}$ spread in the 3 large/main islands in the southeast part of Indonesia: Timor island ( 5 of 6 districts), Sumba island (2of 4 districts) and Flores (6 of 8 districts). The 12 sample districts in each island are listed in Table 1 and map of the Southeast part of Indonesia (map of NTT's Province) is shown in Figure 1.

Table I 12 sample districts taken in the study

\begin{tabular}{lll}
\hline $\begin{array}{l}\text { Timor Island- 5 } \\
\text { districts: }\end{array}$ & $\begin{array}{l}\text { Flores Island - } \mathbf{6} \\
\text { districts }\end{array}$ & $\begin{array}{l}\text { Sumba Island- 2 } \\
\text { districts }\end{array}$ \\
\hline Kupang City & West Manggarai & $\begin{array}{l}\text { Southwest Sumba } \\
\text { (SBD) }\end{array}$ \\
Kupang & Manggrai & West Sumba \\
$\begin{array}{l}\text { South Central } \\
\text { Timor(TTS) }\end{array}$ & East Manggarai & \\
$\begin{array}{l}\text { North Central } \\
\text { Timor(TTU) }\end{array}$ & Ngada & \\
Belu & Ende & \\
& Sikka & \\
\hline
\end{tabular}




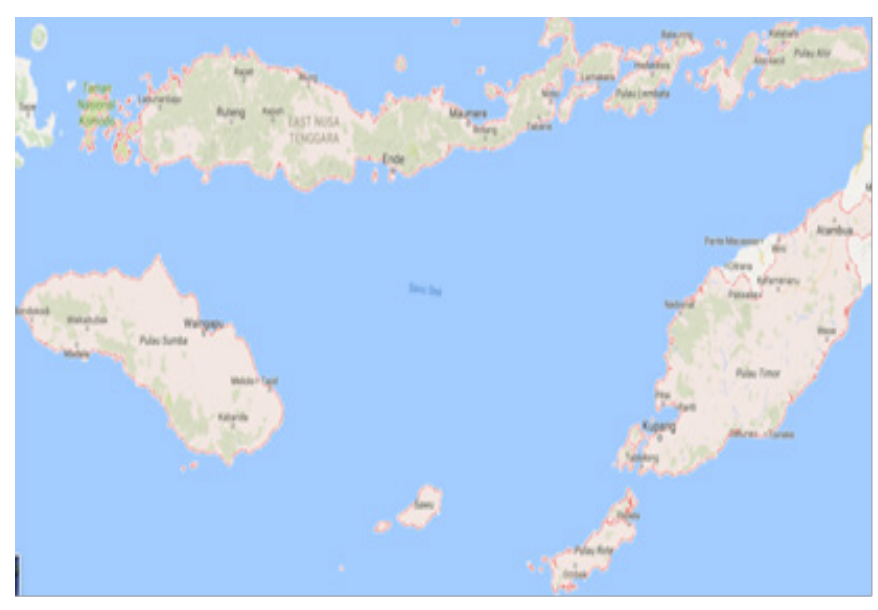

Figure I Map of NTT's Province.

The survey coverage the following actions an steps:

- Interviewe farmers and feedstuffs/foods producers on the field

- Collect data at local market to understand feed availability, identification of traders and collectors

- Interviews to traders on price, producing region, market access logistics, and seasonality.

- Interview to selected producers on production aspects, pricing, seasonality and their capacity.

- Interview to Agency/Department and data collection on pig production, pricing, feed availability, key area of production (for pig and feeds), transport cost, marketing channels and logistics issue.

- Collecting secondary data from Province and district Agricultual departements

- Laboratory analysis of nutritional proximate.

- Colleting feeds samplesat different islands or regions to allow local diversity.

\section{Putak}

\section{Agronomic requirement}

Putak is a local term for the content of gewang/gebang (CoriphagebangaRoxb) stem, a local feed of Timor Island. ${ }^{6}$ Gewang is a type of monoculture palm, the maximum height can reach to $20 \mathrm{~m}$, long live, bearing fruit once and die after fruiting. Gewang reproduces by seeds, grows in lowland and highland that is not rocky with low fertility. Gewang tree can live on muddy ground, but it can not hold standing water for a long period. This palm tree does not need fertilizing and until now there is no any intensive care of human on it. Gewang seeds can be taken after the fruits dried-but mostly are collected after fallen down on the ground or let them seedling naturally-, simultaneously by the time of gewang's death. The look of the sapling and the ready-to be felled gewang to be harvested is shown in Figures $2 \& 3$.

Putak is taken from mature gewang tree before/right in time of flowering and parts of gewang tree. The stem content can be used as Putak in 3 groups based on the heights of trees affected by the age of the tree: high (old) trees with 8 cutlets; middle trees with 6 cutlets and shortest (young) tree with 4 cutlets stem (Figure 4). Gewang tree can produce $600-750 \mathrm{~kg}$ putak at 10-15 years old (on the field interviewe, Figure 4). Putak is only commonly known and used as feeds in Timor while in Flores and Sumba, it has not been used as feeds.

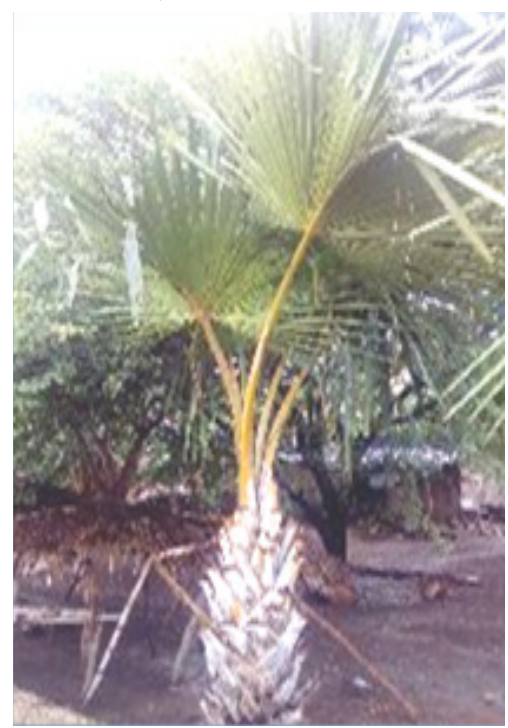

Figure 2 Young Gewang tree.

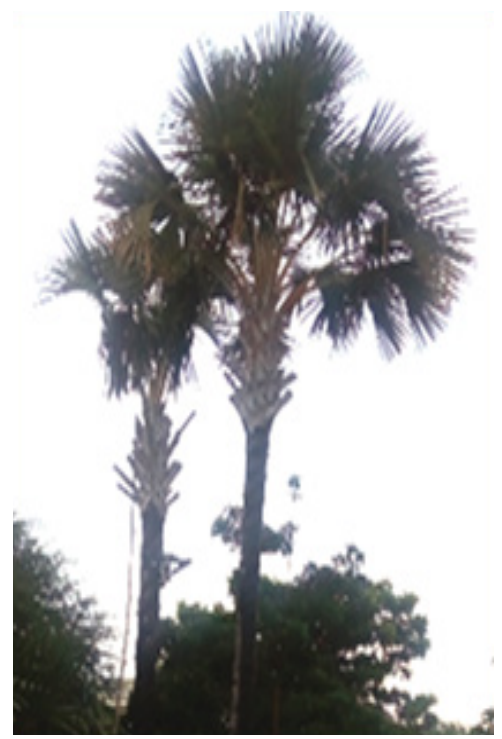

Figure 3 Mature Gewang tree.

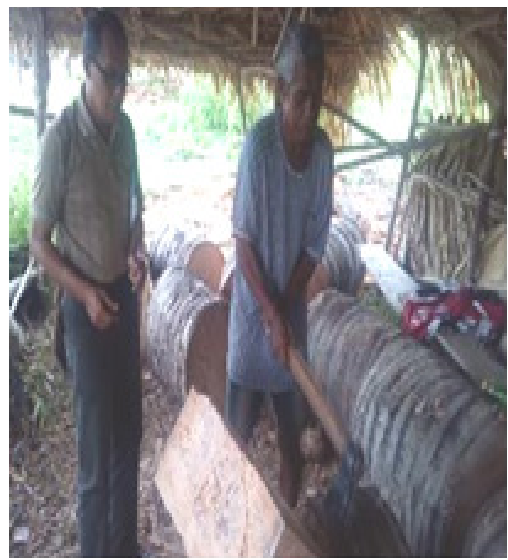

Figure 4 Cutlets of Putak. 
Based on the field interviewthe steps of harvesting Putak according to the loggers are as follows:

- Gewang tree is chosen using a special skill (because not all gewang produces Putak), then is cut down using ax with tradiotional way, but the common and easy way is by using electric saw;

- The part of stem containing Putak which is the part towards the top is separated from the stem with no putak and from the frond (mib and rachis); cut to $\pm 75 \mathrm{~cm}$ size with $40-50 \mathrm{k}$ weight/ cutlet (Figure 4).

- The cutlet then can be cut to be 8-10 of $12-15 \mathrm{~cm}$ thick smaller pieces/cutlet with $\pm 5 \mathrm{~kg}$ weight/piece (Figure 5) and ready to sale that - in commonly traditional ways- will be sliced or chopped-according to the reared livestock type. The pieces are arranged across (Figure 5) to prevent from fungi formation before being sliced or chopped into small particles according to the livestock type. The particle size for cattle or goat is larger $(5-10 \mathrm{~cm})$ than for pigs and poultry is the smallest (usually around the size of corn kernels). For meal purposes in current time, however, the slice stems with putak are peeled and ground with milling mecine (Figure 6) to produce fibrous putak meal which needs filtering (Figure 7).

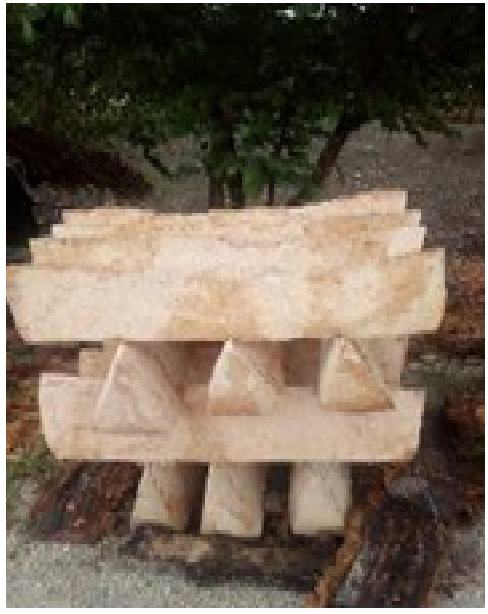

Figure 5 Putak slices.

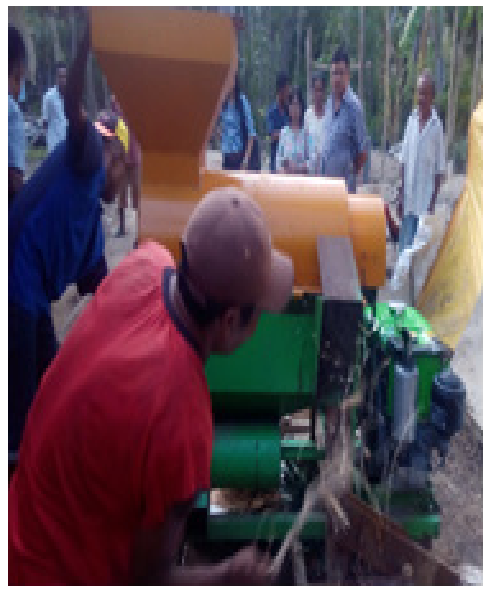

Figure 6 Grinding Putak.

\section{Production trend and seasonality}

Putak productivity (mostly known in Timor Island) is not affected by the season; gewang tree just reduced due to reduced acreage to grow as a result of land use by humans for other purposes. Gewang population is available in Kupang district mostly, with area of $\pm 70 \%$ of the total $\pm 1500 \mathrm{Ha}$ of existing land of Timor Island. Estimated Putak production in Timor is 1000 ton/year. Production tends to decline as the expansion of plantation/fields and settlements.

\section{Availability and locations}

Gewang tree grows throughout Timor Island in the area of not rocky lowland. They do not require fertile soil. However, Putak is not recorded as commodity of agricultural sector, eventhough it has been used as a ruminant feed. ${ }^{6,7}$ Putak of gewang tree can be harvested and used at any time independently of the season, and the productivity/yield has no relationship with rainfall and climate. ${ }^{8}$ Putak highest utilization is during the dry season, namely: August - early of December (before the rainy season) when there is less forage. In the low season of food shortages, people can consume Putak ${ }^{6}$ by choosing softer and easier to chew parts. Utilization of putak is only conducted by local farmers in Timor mainland and used by local Timor farmers; processing for livestock are mostly done in Kupang District. In some locations of Timor Island, gewang is used to produce molasses for beverage or raw material of palm wine. (Table 2).

\section{Price}

Putak is usually sold in pieces as shown in Figure 4 for IDR $10,000 /$ piece, the price has increased since the increase in fuel price from IDR 5,000/ piece equivalent to IDR $1,000 / \mathrm{kg}$ in 2013 to IDR $7,500 /$ piece (IDR 1,500/kg) in 2014 and increase to IDR 2,000/kg since 2015 till now. The stable oil price is estimated to cause stable putak prices in 2020 .

\section{Nutrient content}

Results of Putak Timor proximate analysis seen in Table 3.

Table 3 shows that Putak is an energy-rich feed, suits as a bulk and fiber source. ${ }^{6,7}$ Putak weakness is low in protein and high in crude fiber (CF) from the fiber stem, causing indigestible fiber fraction. Putak is worth considering as pig feed for the entire region in Timor mainland, TTS and TTU. The advantage of Putak for the people on Timor Island is its availability throughout the year.

Optimizing Putak utilization as pig feed is by turning it into flour/mealto easily digested but not increasing the nutritive value. Fermentation using yeast to tenderize the crude fiber and to increase Putak protein value, and the provision of concentrates to supplement protein needs of livestock. ${ }^{6}$

\section{Moringa (Moringaoleifera)}

\section{Agronomic requirement}

Moringa leaf has long been known in region as one of the vegetables that was tasty and fresh. There are two varieties of moringa grown in the region: Green Moringa and Red Moringa. Green moringa is a local variety which grows naturally and has adapted to region's conditions for so long. The shoot, young branch, petiole and young leaf of this variety is green. Moringadoe not need fertile soil or fertilizer. Green moringa also has a high-yielding variety which is being actively developed in region, starting in Timor land. The other variety, Red Moringa, is one of high-yielding varieties that is being developed in region. This variety owns a characteristic, namely: the color of its shoot, young branch, petiole and purplish red young leaf (comparison of the two varieties is shown in Figures 8-10). 
Table 2 The location/district, season and utilization of Putak*

\begin{tabular}{lllll}
\hline District/City & Area $(\mathbf{H a})$ & season & Common Use & Highest Use \\
\hline Kupang City & NA & NA & NA & NA \\
Kupang & 700 & Throughout the year & Feed for pigs, cattle, goats, chickens & August to early December \\
TTS & 50 & Throughout the year & Feed for pigs, cattle & August to early December \\
TTU & 100 & Throughout the year & Feed for pigs, cattle & August to early December \\
Belu & 50 & Throughout the year & Feed for pigs, cattle & August to early December \\
Malaka & 100 & Throughout the year & Feed for pigs, cattle & August to early December \\
\hline
\end{tabular}

(*) Not registered as a commodity in any sectors. NA: not available

Table 3 Results of Putak Timor proximate analysis ${ }^{(*)}$

\begin{tabular}{lllllll}
\hline Material \% & DM & OM & CP & Fat & CF & GE Kcal \\
\hline Putak sliced raw (dry) & 88.1 & 97.1 & 2.9 & 3.6 & 6.6 & 4194 \\
Putak raw flour (dry) & 91.24 & 94.87 & 5.13 & 3.05 & 2.06 & 4114 \\
Putak fermented & 89.1 & 95.4 & 7.3 & 3.4 & 1.8 & 4215 \\
\hline
\end{tabular}

${ }^{*}$ Chemical Laboratory Facultly of Animal Husbandry Nusa Cendana University Kupang-Indonesi (20I7)

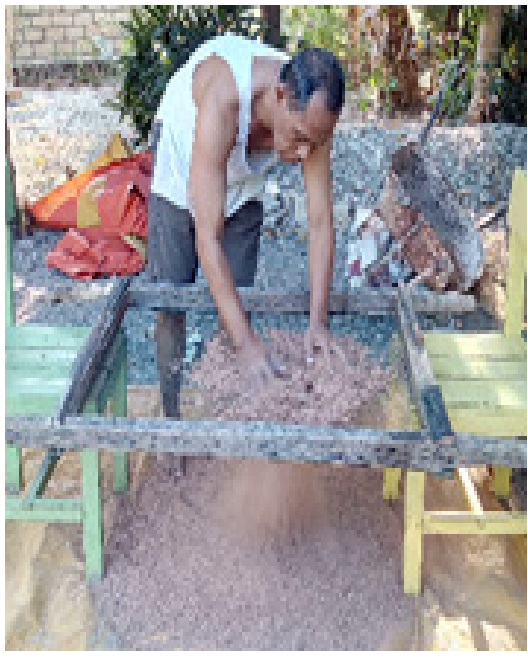

Figure 7 Filtering Putak.

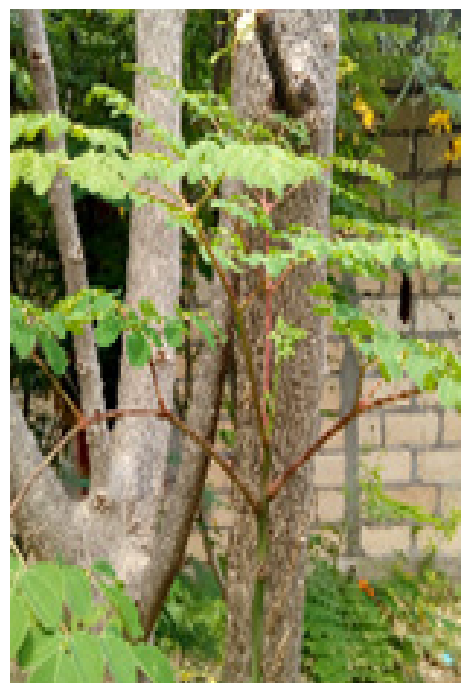

Figure 8 Red moringa.

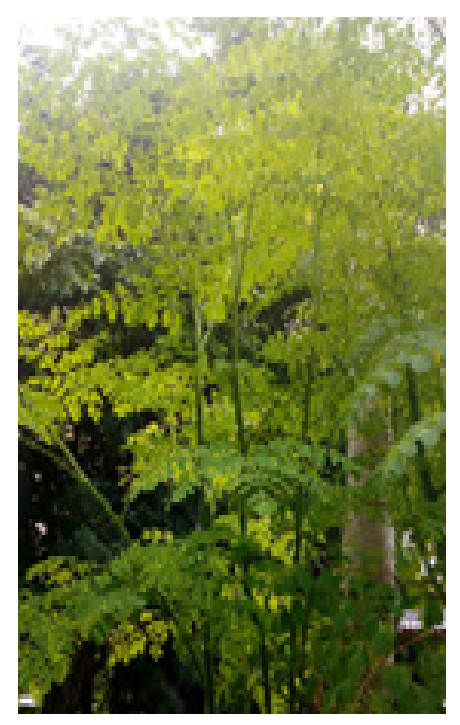

Figure 9 Green moringa.

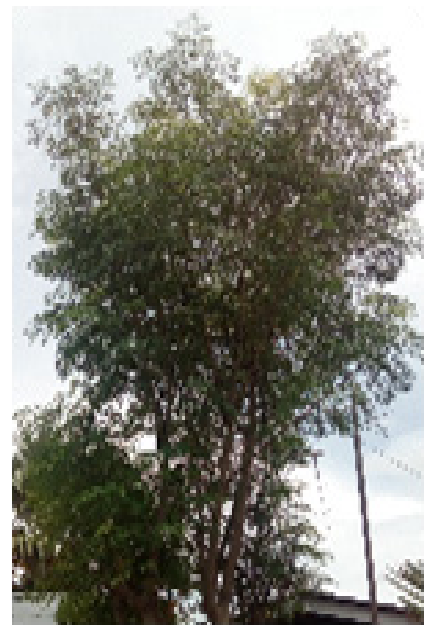

Figure I0 Red moringa with the rest of the rind.

Citation: Ly J, Kristeddy T. Exploring potential locally available feedstuffs for diversifying pig's feeds in dry land area (Part 2: Stem and Leaves sources). Biodiversity Int J. 2020;4(5):224-229. DOI: 10.15406/bij.2020.04.00188 


\section{Production trend and seasonality}

Moringa leaves can be harvested after the tree is $1-1.5 \mathrm{~m}$ high and produces fruit at the age of $1-1.5$ years. Moringa leaves production does not depend on the season. New shoots can appear in dry season, especially if the branch is cut out so that there will be many new shoots with fresh leaves. Moringa leaves production data is not well recorded yet, even though high-yielding moringa varieties have been actively developed.

Although there are no statistical records, but in reality it is showed that moringa leaf production in region is increasing over the last 5 years due to massive moringa cultivations by local governments and private sector by utilizing idle lands in some areas of Kupang's City and District, TTS, TTU and Belu.

\section{Availability (locations)}

Moringa leaf is available all year round, and commonly used as vegetables. Since 2014, moringa leaves have been processed into various forms of products, such as flour, capsules, cakes, and livestock feed. Moringa leaves are generally used as human food, but some experiments have used it as rabbit, goat and pig feeds. Inter-island transportation of fresh moringa leaves are unlikely to occur because moringa can grow in all regions, but transportation of processed products is occurring because export activities have taken place.

\section{Price}

The price of moringa leves during survey period was only detected at 4 following districts and city markets: Oeba and Kasih market (Kupang city), Oesao (Kupang district) and Tambolaka (SBD district). At those 4 markets, the leaves are sold uniformly in a bundle (1012 petioles/bundle; Figures 11\&12) at a price of IDR 2,000-2,500/ bundle.

Moringa leves prices increased by 3 years after intensive disseminations of moringa leaves benefits for humans. In 2013-2014 the price was IDR 1,000-1,500/bundle, then in 2015-2016 it increased to IDR 2,000-2,500/bundle.

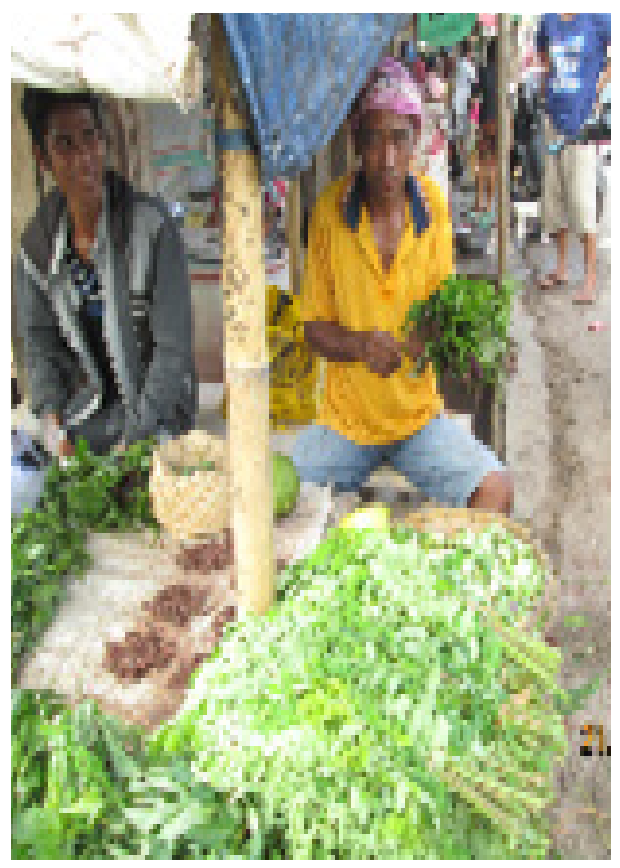

Figure I I Moringa leaves in Tambolaka (SBD).

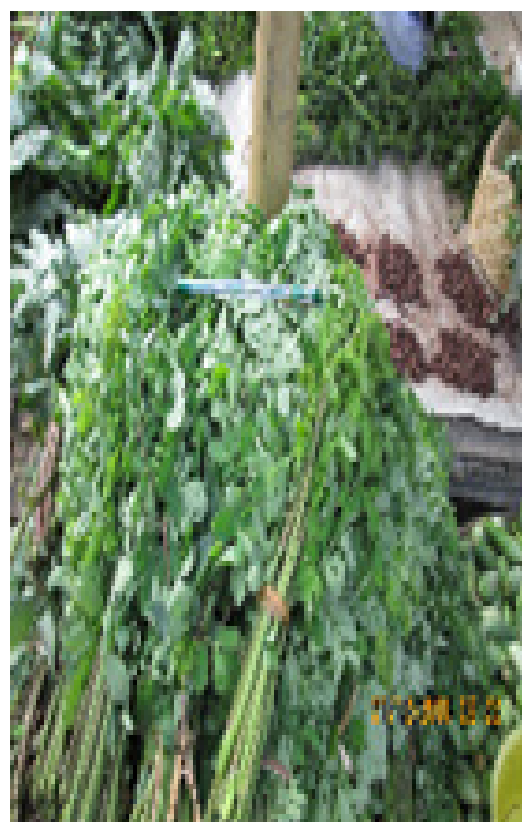

Figure 12 Bundles of red moringa in SBD.

\section{Nutrient content}

Collective moringa leves nutrient composition is shown in Table 4 .

Table 4 The composition of nutrients of Timor's fresh Moringa leaves ${ }^{(*)}$

\begin{tabular}{llllllll}
\hline Material & DM & CP\% & Fat\% & CF\% & Ca\% & P\% & $\begin{array}{l}\text { GE } \\
\text { Kkal/Kg }\end{array}$ \\
\hline $\begin{array}{l}\text { Fresh } \\
\text { leaves }\end{array}$ & 7 & 24.5 & 6.3 & 5.7 & 2.7 & 3.5 & 3580
\end{tabular}

(*)Proximate Analysis Laboratory of Animal Nutrition Undana 2017. DM, dry matter; $\mathrm{CP}$, crude protein; $\mathrm{CF}$, crude fiber

Table 4 shows that moringa leaves are high in protein, $\mathrm{Ca}, \mathrm{P}$ and energy but low in crude fiber, making it suitable for protein source feed. The downside of Moringa leaf is bitter when applied in large quantities. Moringa tree can grow in all types and levels of soil fertility, and leaf production takes place throughout the year. It propagates from seeds and grafting, and produces fruit during dry season. The data of presence, production and availability of moringa leaves have not yet been recorded in statistical data, but in reality moringa tree is being actively developed in REGION both by government and private institutions, and moringa leaves have commonly sold in the markets as vegetables, and in the food and drugstores as supplement and herbal medicine. Moringa leaf has been known long ago by region community as vegetables, and it has been investigated as feed for pigs, goats and rabbits. Nutritional composition showed that Moringa leaf is a rich in protein vegetable so that it can be used as a green supplement. The nutritional value of Moringa leaves can be maximum utilized by pigs by drying and milling or soaking the fresh leaves into water or pulping the leaves before feeding.

\section{Conclusions and recommendations}

The 2 feedstuffs have adapted to the region's climate, both do not fertilizer to increase productivity. The availability of Putak is independently of season, but moringa leaves productivity is naturally low during dry season in most regions. Putak is fibrous with low protein content and need additional treatment to maximum utilized 
by pig; it can not be used as single feed for pig. Moringa leaf contains high protein and highest value for pig can be achieved by drying and milling, or soaking the fresh leaves into water, or pulping the fresh leaves before feeding. Moring leaves meal can be used as a green supplement for pig.

\section{Recommendations}

Putak should be preserved as a NTT's special feedstuff by intensive care and protect gewang tree from illegal cutting. Study on the way to enriching nutritional value and utilization of putak for pig can carried out in future. Production and utilization of moringa leaf as green feed for pigs and livestock is important to carry.

\section{Acknowledgments}

Thankful is addressed to ARISA for funding the study and all related departments that provided secondary data for the survey.

\section{Conflicts of interest}

The Author declares there are no conflicts of interest.

\section{References}

1. NTT in Figures. Nusa Tenggara Timur in Figures. Statitics of Nusa Tenggara Timur Province. Statistics Bureau of Nusa Tenggara Province 2016
2. Johns C, Cargill C, Patrick I. Smallholder commercial pig production in NTT - opportunities for better market integration. SADIACIARSMAR/2007/195. 2009.

3. Ly J, Ginting UM, Likadja RDH. Pig Production in Nusa Tenggara Timur, the Semiarid Regions. Paper presented in: ACIAR and Udayana University Pig Production in Eastern Indonesia Workshop. 2010.

4. Ly J, Kristeddy T. Exploring potential locally available feedstuffs for diversifying pig's feeds in dry land area: Fruits, Tubers and seeds groups. Biodiversity Int J. 2019;3(3):101-108.

5. Agricuture Census. Agriculture Census 2013 Survey Result of Nusa Tenggara Timur Province Statistics Bureau. 2013.

6. Hilakore MA. Improving putak nutritive quality using mixed culture Trichodermareesei and Aspergillusniger as ruminant feed. Disertasion. 2008 .

7. Nalle Cl, Yowi MRK, Tulle D. Nutritional Value of Putak: Apparent Metabolisable Energy, and Growth Performance. International Journal of Agriculture System (IJAS). 2017;5(1).

8. Peprah K. Rainfall and Temperature Correlation with Crop Yield: The Case of Asunafo Forest, Ghana. International Journal of Science and Research (IJSR). 2015;3(5):784-789. 